\title{
Alive and well: the good faith principle in Turkish contract law
}

\author{
Hans-Bernd Schäfer ${ }^{1} \cdot$ Hüseyin Can Aksoy
}

Published online: 26 March 2015

(C) Springer Science+Business Media New York 2015

\begin{abstract}
Good faith is a principle prominent in civil law countries but less so in common law countries, and which allows courts to deviate from black letter law. It provides them with flexibility to change the outcome of a deductive legal decision if they regard it as absurd. The principle of good faith thus empowers the judiciary to deviate. It can be used for an indefinite number of cases and might lead to almost all conceivable legal consequences. For instance, the judge can invalidate the contract, change the price, suspend or change a clause in the contract, or grant injunctive relief, compensation of damages, the disgorgement of profits or a removal claim. We argue that if the principle of good faith is used to develop contract law into an instrument for redistributing wealth in favor of poor parties, this can destroy the concept of contract as a social mechanism for generating mutual gains for parties, which might lead to unwanted economic consequences in terms of efficiency losses. We argue that the principle of good faith must be carefully and reluctantly used to reconstruct the fully specified contract and that well-informed judges, who understand the factual environment of a contract well should ask how fair bur selfinterested parties would have allocated the risk in a pre-contractual situation. If the courts restrict the application of the good faith principle to these functions, this provides elasticity that otherwise would not exist if courts would strictly use the rules laid down in black letter law. Moreover, it saves transactions costs and is therefore in line with economic reasoning. We look at the most important Turkish
\end{abstract}

Hüseyin Can Aksoy

hcaksoy@bilkent.edu.tr

Hans-Bernd Schäfer

hans-bernd.schaefer@law-school.de

1 Bucerius Law School, Hamburg, Germany

2 Faculty of Law, Bilkent University, Ankara, Turkey 
cases and find that the Turkish Supreme Court following Continental European doctrines of good faith actually uses this principle to curb opportunistic behavior of parties and not to achieve redistribution from the rich to the poor by way of interfering into contract law.

Keywords Good faith principle · Risk distribution - Contract law · Turkish law

\section{JEL Classification K12 Contract Law}

\section{Introduction}

From an economic perspective the default rules of contract law try to mimic the fully specified contract. They allocate risk to the cheapest cost avoider or the cheapest insurer. They also specify norms for curbing opportunistic behavior, which leads to an unwanted redistribution of wealth between parties rather than increasing each party's wealth. Thus contract law tries to allocate risks and imposes contractual, pre-contractual and post-contractual duties, ideally in a way which fair but self-interested parties would have chosen themselves had they cared to specify them. However, the rules as laid down in the law might sometimes lead to unintended and absurd consequences. They might fit for many, yet not for all cases.

Good faith is a principle prominent in civil law countries but less so in common law countries, which allows courts to deviate from black letter law. It provides them with flexibility to change the outcome of a deductive legal decision if they regard it as absurd. The principle of good faith thus empowers the judiciary to deviate. The alternative to such a flexible blanket clause would probably not be an equally flexible contract law, which is continuously updated by parliaments, but stickiness and incapacity to react to unforeseen problems of adjudication. Parliaments cannot change the laws as often as would be required. They cannot micromanage contract law. If principles such as good faith are not used, one consequence would be that the law cannot adapt to new situations, thus lacking innovativeness and convincingness in terms of outcome. Another consequence is that parties write long contracts containing all contingencies and parties' duties in order to come close to a fully specified contract and thus heavily invest in defensive measures against opportunism. This might explain as to why contracts in legal orders that only use the good faith principle reluctantly, like in England, are often much longer than in civil law countries like Germany, where contracts are less complete and shorter. Parties are then incentivized to write contingencies into the contract and do not rely to the same extent on adjudication and interpretation. If however the good faith principle is used parties might be able to place their trust in courts, particularly the latter's capability for acting as their agent and finding the decision which ex-ante at contract formation they would have chosen themselves. The downside is the higher transactions costs of forming the contract. 
The principle of good faith gives much power to the judiciary and this power can be, and has been, misused for various purposes. Primarily, it can be misused through the import of ideology into contract law. ${ }^{1}$ Ideological import can bring about changes to contract law through the misuse of the good faith principle and the flexibility that it entails. Another danger is that it might lead to judicial activism, if the judiciary encroaches the legitimate function of parliament and democracy, and the judiciary develops the law through the principle of good faith in such a way that it - to some extent-replaces parliament. Another and perhaps the main problem today is the overuse of the concept by the judiciary under the name of "maintaining justice", with which social justice is meant, that is the redistribution of wealth from the rich to the poor party. Still another disadvantage, in line with Hayek's reasoning, is that many important clauses of a contract on which parties and the black letter law remain silent are stipulated by judges, who as outside observers may not possess the information for acting in the ex-ante interest of all parties, even if they have the best intentions on doing so.

In this article, we discuss the principle of good faith from an economic perspective, relating this to cases of the Turkish Supreme Court. We deal with objective, contractual good faith and leave aside subjective good faith in property law, which might - depending on the case-result in acquisition of ownership by a good faith purchaser. We argue that if the principle of good faith is used to develop contract law into an instrument for redistributing wealth in favor of poorer parties this can destroy the concept of the contract as a social mechanism for generating mutual gains for parties, which might lead to unwanted economic consequences in terms of efficiency losses. We argue that the principle of good faith must be carefully and reluctantly used to reconstruct the fully specified contract, and that well-informed judges who understand the factual environment of a contract should ask how the parties would have allocated the risk in a pre-contractual situation. We also examine and discuss the most important landmark cases on good faith in Turkish contract law and ask whether the decisions of the Supreme Court can be understood either as efforts to improve risk allocation in a contract and to remove opportunistic behavior, therefore offering a valuable service to parties; or whether these decisions reflect the motivation to redistribute wealth ex-post or to serve an ideological purpose, therefore affecting or destroying the private autonomy on which contract law is based.

\footnotetext{
1 The principle of good faith, like other blanket clauses in civil law, had been badly misused during the period of totalitarianism which existed in the Soviet Block as well as in Nazi Germany, distorting the formal rules of contract law in favor of ideology and the party line. In Nazi Germany, the principle was misused to avoid contracts that did not follow the political line of the ruling party. After being occupied by the Soviet Russia, all judges in East Germany who were contaminated with Nazism were dismissed. Therefore there were almost no remaining judges in the East Germany. The solution to this obstacle was found to be the training of new judges within a short period of time. New judges were trained within 6 months, and they were especially educated in using the good faith principle. A similar development was observed in Russia after the Russian revolution, when blanket clauses in contract law were instruments for adapting the function of contract law to serve ideological purposes (Reich 1972). In Soviet Russia after the revolution, the inflationary use of blanket clauses in contract law was observed. After the revolution the first idea was to replace the old civil law by a new socialist civil law. However, realization of such a project proved to be too difficult in practice. In the end, the rulers figured out that they could use blanket clauses, such as good faith principle, to overcome such obstacles.
} 


\title{
1.1 A comparison of contract law with and without the good faith principle
}

Over the last decades, the good faith principle has been extended to worldwide use. It is, for instance, contained in the US Uniform Commercial Code ${ }^{2}$ as well as in the UN Sales Law. ${ }^{3}$ Likewise, in European Union law the principle of good faith is contained in various rules on consumer protection. ${ }^{4}$ It also shows up in the Principles of European Contract Law $^{5}$ of the so-called Lando Commission and in the UNIDROIT Principles for Commercial Contracts. ${ }^{6}$

\begin{abstract}
${ }_{2}^{2}$ References to good faith can be found in various articles of the UCC. In particular see § 1-304 titled as "Obligation of good faith": "Every contract or duty within [the Uniform Commercial Code] imposes an obligation of good faith in its performance and enforcement." Despite this provision, in the United States courts and scholars have tried to agree on the exact meaning of the concept (Miller and Perry 2013: 694).Summers (1968: 195) regards good faith as an excluder which "has no general meaning or meanings of its own, but which serves to exclude many heterogeneous forms of bad faith". For the distinguishable types of bad faith in contract case law see Summers (1968: 233 ff.). Summers'(1968) "excluder approach" is recognized in the Restatement. In Restatement (Second) of Contracts, $\$ 205 \mathrm{a}$, it is stated that "Good faith is defined in Uniform Commercial Code § 1-201(19) as "honesty in fact in the conduct or transaction concerned." "In the case of a merchant" Uniform Commercial Code § 2-103(1) (b) provides that good faith means "honesty in fact and the observance of reasonable commercial standards of fair dealing in the trade." The phrase "good faith" is used in a variety of contexts, and its meaning varies somewhat with the context. Good faith performance or enforcement of a contract emphasizes faithfulness to an agreed common purpose and consistency with the justified expectations of the other party; it excludes a variety of types of conduct characterized as involving "bad faith" because they violate community standards of decency, fairness or reasonableness. The appropriate remedy for a breach of the duty of good faith also varies with the circumstances." Burton (1980) diverges from Summers' definition and relates bad faith to the exercise of discretion by one of the contractual parties with respect to certain aspects of the contract, such as quantity, price, or time. According to the author, "Bad faith performance occurs precisely when discretion is used to recapture opportunities forgone upon contracting - when the discretion-exercising party refuses to pay the expected cost of performance. Good faith performance, in turn, occurs when a party's discretion is exercised for any purpose within the reasonable contemplation of the parties at the time of formation-to capture opportunities that were preserved upon entering the contract, interpreted objectively. The good faith performance doctrine therefore directs attention to the opportunities forgone by a discretion-exercising party at formation, and to that party's reasons for exercising discretion during performance." (Burton 1980: 373). Another major account of the duty of good faith performance under common law is "commutative justice", which refers to the "enforcement of the parties' actual agreement" (Miller and Perry 2013:712). Accordingly, the good faith principle protects the reasonable expectations of the parties which they had while contracting.
\end{abstract}

${ }^{3}$ See Article 7(1) CISG: "In the interpretation of this Convention, regard is to be had to its international character and to the need to promote uniformity in its application and the observance of good faith in international trade".

${ }^{4}$ See Article 3(1) of Council Directive 93/13/EEC of 5 April 1993 on unfair terms in consumer contracts: "A contractual term which has not been individually negotiated shall be regarded as unfair if, contrary to the requirement of good faith, it causes a significant imbalance in the parties' rights and obligations arising under the contract, to the detriment of the consumer."

${ }^{5}$ Reference to good faith can be found in various articles of the Principles of European Contract Law (PECL) including Articles 1:102, 1:106, 1:201, 1:302, 1:305, 2:301, 3:201, 4:102, 4:107, 4:109, 4:110, 4:118, 5:102, 6:102, 6:111 and 8:109 PECL. In particular see Article 1.201: "(1) Each party must act in accordance with good faith and fair dealing. (2) The parties may not exclude or limit this duty."

${ }^{6}$ Reference to good faith can be found in various articles of the Principles, including Articles 1.7, 4.8, 5.1.2, 5.3.3, 5.3.4. In particular see Article 1.7: "(1) Each party must act in accordance with good faith and fair dealing in international trade. (2) The parties may not exclude or limit this duty." For a reference to bad faith see Article 2.1.15. 
In spite of its dangers, it seems that there is general tendency to trust it as an instrument for improving the beneficial properties of contract law as a win-winmechanism and not in order to impede it. ${ }^{7}$ However, English courts still reject the good faith principle. ${ }^{8}$ In an often-quoted decision made by the House of Lords in 1992, the duty to negotiate in good faith was rejected on the ground that it runs counter to the antagonistic interests of parties in business relations. ${ }^{9}$ English courts maintain the view that courts should interpret but not change contractual obligations. ${ }^{10}$ In other words, English courts are more inclined to leave it to the parties to allocate all risks themselves (Musy 2000: 6; Goode 1992: 2). ${ }^{11}$ This is not to say that flexible methods of

\footnotetext{
7 Hesselink (2010: 645) states that good faith is not a norm of private law, let alone of contract law. It is merely an instrument that the judge applies to create new rules. Good faith is "merely the mouthpiece through which new rules speak, or the cradle where new rules are born." This results from the fact that in continental European systems, a judge perceives himself as the person who applies the law but refrains from creating a rule, changing an adopted rule or interfering with the contractual right of party autonomy (i.e. what parties freely agreed to). Therefore the judge needs to refer to concepts like good faith that have already been adopted by the democratically elected legislator.

8 "Faced with a problem in contract, the Common lawyer is as likely as not to try to solve it with an implied term. But the Civil lawyer will probably resort to a rule, whether it be a broad and fundamental precept such as the German requirement of good faith (Treu und Glauben)..." (Nicholas 1973: 950). Common law lawyers regard the good faith principle as "....an invitation to judges to abandon the duty of legally reasoned decisions and to produce an unanalytical incantation of personal values." (Bridge 1984: 413); see also Zimmermann and Whittaker (2000: 15 ff.) According to Steyn (1997: 442), there is no need to adopt a good faith principle in English law as long as the courts take into consideration the reasonable expectations of the parties in accordance with the own pragmatic tradition of English law. For arguments that other mechanisms in English law lead to some of the legal results that are achieved via the good faith principle in other legal systems see also Zimmermann and Whittaker (2000: 45 ff.) On the other hand, according to Piers (2011), good faith has always played an important role in English law, without an explicit reference to the concept. However, unlike civil law countries, it has never taken root as a general principle. Piers (2011) explain this with the difference between the civil law and common law systems, in the sense that the civil law's deductive method of reasoning leads to the creation of and reference to abstract principles such as good faith as the foundation of practical findings. On the other hand, common law's inductive reasoning constitutes a structural reluctance to adopt overarching, general principles. (Piers 2011: 167-168).

9 “...the concept of a duty to carry on negotiations in good faith is inherently repugnant to the adversarial position of the parties when involved in negotiations. Each party to the negotiations is entitled to pursue his (or her) own interest, so long as he avoids making misrepresentations." Walford v. Miles [1992] 2 AC 128, 138. See also Zimmermann and Whittaker (2000: 39 ff.).

${ }^{10}$ Teubner (1998) argues that this divergence of English law can be explained by the liberalization of the world markets that has led to the establishment of more than one form of capitalism (Teubner, p. $24 \mathrm{ff}$ ). According to the author, "the British economic culture does not appear to be a fertile ground on which continental bona fide would blossom." (Teubner 1998: 27). Laithier (2003: §II B 1) objects to this argument, stating that if such analysis were correct, American and Scottish legal systems, which are subject to similar type of capitalism, would also not recognize good faith.

11 However, Goode (1992: 1) states that unlike the old common law, the modern English courts "... began to try to help the weaker party, as by reducing the rigour of the caveat emptor rule in the sale of goods and by imposing certain duties of good faith in a range of other situations". For detailed information on good faith in English law, see O'Connor (1990); Whittaker (2013). On the assessment that Anglo-Canadian law does not need to legislate a standard of good faith, see Bridge (1984: 425).
} 
interfering with contracts do not exist in English contract law; however, these have a more limited scope than the broad and overarching good faith principle. ${ }^{12}$

What is the consequence of this? If parties are themselves expected to explicitly allocate risks and remove contingencies - potentially leading them into the temptation of acting opportunistically — with one of the parties forced to otherwise bear the consequences, both parties will have higher incentives to do so than in a jurisdiction in which such usually remote risks are allocated through court decisions. This makes contracts potentially more authentic. But parties will also spend more time and effort on allocating risks. Consequently, drafting a contract is more costly in a jurisdiction in which the principle of good faith does not exist and in which the authority of courts to intervene with a contract is more limited. In fact, it is well known that contracts are much longer in England than, for instance, in Germany where the good faith principle is extensively used, and therefore contracts are also more costly. In England, contracts often contain long laundry lists of duties, obligations, non-competition clauses and other risks that are explicitly taken care of, whereas this cannot be observed to the same extent in German contracts. ${ }^{13}$

If one compares the two solutions, there is an upside and a downside to each of them. The self-restraint of English courts takes the will of the parties as displayed in the contract itself more seriously. The extended use of good faith, however, provides the parties with a valuable public service that serves the same purpose as the rules of contract law themselves, namely to fill in gaps in incomplete contracts (Ayres and Gertner 1989: 87) and to reduce pre-contractual and post-contractual opportunistic behavior in parties. ${ }^{14}$ If

\footnotetext{
12 According to Piers (2011: 168-169), English courts and scholars are increasingly inclined to apply rules guided by the notion of good faith and exploring the implications of the principle. Following the opinion that English law already applies a variety of good faith-related principles, Sims (2004: 232) states that "This is best visualised as a set of circles, concentrically placed around the basic moral notion of honesty, which is the minimum standard of behaviour required by the law from all contracting parties. From this centre point, the different applications of good faith spread out in ever widening circles." Lord Bingham expressed a similar view with the following words in Interfoto Library Ltd. v. Stiletto Ltd. (1988) 2 W.L.R. 615 (p. 621): (England has no) "overriding principle that in making and carrying out contracts parties should act in good faith" but added that on the other hand "English law has, characteristically, committed itself to no such principle but has developed piecemeal solutions in response to demonstrated problems of unfairness".

13 Referring to the different approaches of the civil law system and English law with regard to good faith, Sims (2004: 232) argues that the legal methodology remains the same. Therefore it is not surprising that when developing their law of "Treu und Glauben", German courts adopted a common law technique by building up a body of case law to clarify the individual applications of the overarching concept.

14 Mackaay and Leblanc (2003: 26) regard good faith as the opposite of opportunism and propose a three-step test to operationalize opportunism: "an asymmetry between the parties; which one of them seeks to exploit to the detriment of the other in order to draw an undue advantage from it; the exploitation being sufficiently serious that, in the absence of a sanction, the victim and others like him or her are likely substantially to increase measures of self-protection before entering into a contract in the future, thereby reducing the overall level of contracting." In fact, Mackaay (2009: 12) defines bad faith as the legal term for opportunism. Opportunistic behavior is inefficient because it encourages parties to take precautions and write longer contracts in order to deter such behavior and legal uncertainty. This increases transaction costs and reduces the net gain from the contract (Sepe 2010: 27; Mackaay 2011: 20). The ultimate precaution would be to forego a contemplated contract altogether, and if many potential contractors were to follow this behavior, the entire market would shrink (Mackaay 2011: 13). Mackaay (2011: 20) perceives good faith as a last resort tool for preventing opportunistic behavior. In fact, the law provides a range of specific anti-opportunism concepts, yet sometimes no such concepts will be able to curtail a specific manifestation of opportunism. In such cases, courts will resort to good faith.
} 
courts can be trusted to restrict themselves to this purpose, the good faith principle is preferable. ${ }^{15}$

In those countries that accept the principle of good faith there is a general scholarly agreement that the good faith principle, which can fundamentally change a contract, should be used as a last resort where the formal rules of contract law would otherwise lead to absurd consequences. This opinion has also been expressed by the Turkish Supreme Court in its decision from 1984: “...with the rule set forth under Article 2/2 of the Civil Code, an exception is brought to the absoluteness of the Law and right. However, also considering the subsidiarity of this rule, at first the relevant legal provisions shall apply to each case; in some exceptional cases, where the legal provisions which apply cause unjust results, the rule under Article 2.2. Can be resorted to in a way to correct the injustice." ${ }^{16}$ This is to be welcomed but it seems that this self-restraint was not followed in all cases. We present here an old case, ${ }^{17}$ in which in our view the Turkish Supreme Court resorted to the good faith principle prematurely and not as a matter of last resort. Under Turkish law, tenants are protected against termination of contract with some exceptions. One exception is the personal use of the property by the flat owner. The real estate owner sold one percent of his ownership rights to a third person, who then claimed to need the flat for his personal use and wanted to evict the tenant. The Supreme Court came to the conclusion that this transaction was made for the sole purpose of evicting the tenant and circumventing the rules that protect him, and that the owner of the one percent share had no real interest in using the flat for his own purpose. It concluded that this fake transaction violated the principle of good faith. This would not have been necessary given the facts of the case because if the new owner had no intention to use the flat for himself but only to feign use in order to evict the tenant this would have amounted to a fictitious transaction, therefore immediately invalidating his claim without creating the need to use the good faith principle.

\footnotetext{
15 Despite the large ideological difference between the Continental-European legal system and English law, in practice there is no substantial difference between the two legal systems. Goode explains the similar opinion with the following words: "In many cases we arrive at the same answers as you but by a different route. Thus there are numerous situations in which we do not find it necessary to require good faith because we impose a duty which does not depend on good faith." (Goode 1992: 4).

16 Own translation from Turkish: “... Medeni Kanunun 2/2. maddesindeki kuralla, Kanunun ve hakkin mutlaklığı kuralına istisna getirilmektedir. Ancak, bu kuralın taliliği (yani ikinciliği) de gözetilerek; öncelikle her meseleye ona ilişkin kanun hükümleri tatbik edilecek; uygulanan kanun hükümlerinin adalete aykırı sonuçlara neden olabildiği bazı istisnai durumlarda da, 2/2. maddedeki kural, haksızlığı tashih edici bir şekilde uygulanabilecektir." Yarg. IBGK, 25.1.1984, E. 1983/3, K. 1984/1. In the same vein, see also Schwarz (1946): 204; Dural and Sarı (2010: 215); Sungurbey (1974: 123); Oğuzman and Barlas (2008: 258-259); Akyol (2006: 17); Merz (1962: Art. 2, N. 49); Oğuzman (1988: 408). For a study on redundant references to the good faith principle in Turkish Supreme Court decisions, see Oğuzman (1988: 407 ff); also see Oğuzman and Barlas (2008: 260, fn. 369).
}

17 Yarg. 6 HD 8.6.1953 1953/5970, K. 1953/4240. 


\subsection{Economic functions and pitfalls of the good faith principle}

\subsubsection{Income redistribution with efficiency losses}

Good faith as a mechanism for maintaining fairness and redistributing wealth Fair contracts are win-win constellations that make all parties better off (Veljanovski 2007: 111). If such contracts do not carry adverse effects on third parties, they are mechanisms for generating Pareto improvements (Cooter and Ulen 2012: 283; Shavell 2004a: 61, b: 293), which welfare economists regard as the most obvious and the least debatable societal improvement. The role of contract law is therefore to allocate risks in a cost-efficient way and to keep the contract fair by curbing opportunistic behavior which might occur before or after the conclusion of the contract, leading to an unwanted transfer of wealth from one party to another. The whole body of contract law can be conceptualized as an endeavor to guarantee the fairness of contracts in the sense of avoiding opportunistic behavior(Posner 2007: 94; Kaplow and Shavell 2002: 1705) as well as the cost-efficient allocation of risk (Harrison 1995: 91; Schwartz 2003: 143, Schäfer and Ott 2004: 277). The welfareoriented economic underpinning of the contract as a Pareto improvement or at least a win-win constellation between parties involved is not questioned but supported by all of these contract law rules. Therefore any rule of contract law redistributing wealth between parties in such a way that self-interested but fair and nonopportunistic parties would never have agreed upon questions the very idea of the contract as a mechanism for increasing wealth. Accordingly, if the good faith principle would be used to change the distribution of wealth in a society, it would come under critique because this is not a consented policy target of contract law.

It is obvious that not only the contracts as stipulated by the parties themselves, but also that textbook contract law with its collection of default and mandatory rules is incomplete, with new constellations arising that in turn raise new questions. If the good faith principle were used exclusively in order to curb opportunistic behavior and to allocate risks in a cost-efficient way, little room for controversy would exist. The suspicion against the good faith principle is, however, that it opens up the possibility for courts to fix terms of contract, which fair but self-interested parties would never have agreed to, which aim at redistributing wealth from one party to the other and which question the win-win property of the contract. ${ }^{18}$ If this happened, parties would react to this by not concluding a favorable contract that makes both parties better off. This could lead to huge negative effects for the economy. We illustrate this with two obvious cases:

Example 1 Contract law usually contains a rule under which the partial delivery of the specific performance can be rejected. ${ }^{19}$ If for instance a supermarket buys a thousand packs of rice, the seller is not entitled to make the delivery in several parts.

\footnotetext{
18 According to Sepe (2010: 57), good faith should be a default rule rather than a mandatory rule, because the parties are in a better condition to evaluate the efficiency condition for good faith. Therefore, the parties must be given the option to choose a literal interpretative regime, where the contract serves as the only evidentiary base that the courts will use when enforcing their agreement.

19 For instance, this is explicitly set forth under Article 84 (1) of Turkish Code of Obligations.
} 
The rationale for this rule is that it saves costs for the buyer who may otherwise get too much distracted from accepting and storing the merchandise. Assume that the buyer, whom the law entitles to a complete delivery, discovers that one bag is missing. Has the buyer then a right to refuse specific performance? It is obvious here that the delivery of a bag 1 day later would not distort business but to insist on full delivery later might impose huge costs on the seller. Therefore the parties, had they allocated this risk in a fully specified contract in the pre-contractual situation, would have suspended the general rule of contract law for this specific case. If the principle of good faith does the same and suspends the formal rule by not allowing one party to insist upon his rights- particularly when he has no or only a trivial advantage but would in turn cause a great loss to the other party-the principle of good faith provides a valuable service because it does not impose a rule to which selfinterested but fair parties would not have agreed in the pre-contractual negotiations. $^{20}$

Example 2 This example refers to a case of Brazilian contract law, in which the Supreme Court prolonged a rental contract for an indefinite period of time. ${ }^{21}$ In Rio de Janeiro, a landlord rented his house to a tenant who used the house as an asylum for the elderly. However, the tenant failed to pay his rent for consecutive months. Therefore, the landlord applied to the Court and asked for the tenant to be evicted. In fact, it is set forth under the Brazilian Landlord-Tenant Law (Law No. 12112/2009) that the landlord can evict the immovable when the tenant fails to pay the rent stipulated in the contract. In its decision of 2012, the Appeal Court of Rio de Janeiro prolonged the deadline given to the defaulting tenant to leave the rented house forming order to protect the elderly residents of the asylum. ${ }^{22}$ The Court stated that the "social function of the contract" is one of the contract law pillars and is related to the human dignity which is protected under the first article of the Brazilian Federal Constitution, allowing for a more humane perspective in spite of a predominantly profitable vision. ${ }^{23}$ In this case, the court using the principle of good

\footnotetext{
${ }^{20}$ Here, one can quote the opinion of Justice Posner from the decision Market Street Associates Limited Partnership v. Frey, 941 F. 2d 588, 595: "The concept of the duty of good faith like the concept of fiduciary duty is a stab at approximating the terms the parties would have negotiated had they foreseen the circumstances that have given rise to their dispute. The parties want to minimize the costs of performance. To the extent that a doctrine of good faith designed to do this by reducing defensive expenditures is a reasonable measure to this end, interpolating it into the contract advances the parties' joint goal." According to Sepe (2010: p. 19, fn. 53), this is one of the clearest descriptions of the law and economics approach to good faith.

21 We thank Flavianne Fernanda Bitencourt Nóbrega for valuable information on the good faith principle in Brazil. She provided us with cases and informed us on Brazilian and Latin American legal developments regarding good faith in contract law, especially the dogmatic concepts of "social function of a contract" and "constitutionalization of contract law" which extends human rights, originally rights vis-à-vis the state, to the contractual partner.

22 Decision of the Court of Appeal-Rio de Janeiro-Appeal Process Number: RJ 0024579-49.2010.8.19.0004, Court Judge: Des. Ademir Pimentel, Date of Judgment: 01/06/2012, Thirteenth Civil, Landlord: Ivan Felippe, Tenant: Ezio Huais.

23 The new Brazilian Civil Code, enacted in 2002 and which came into force in 2003, introduced two important general clauses: "social function of contracts" and "objective good faith". These general clauses were codified, respectively, in Article 421 and Article 422 in the chapter of General Provisions of Contracts. The legal provision of Article 421 says ipsis litteris that "the freedom to contract shall be
} 
faith and the derived principle of "the social function of contract" ${ }^{24}$ prolonged the duration of the contract for an indefinite period. ${ }^{25}$ In other words, the principle of good faith was used to prevent evacuation of the flat, making the landlord a charitable donor.

If we compare this latter case with the former case, the difference is striking. In a pre-contractual situation, the landlord would most probably never have agreed to such a clause in the contract if both parties had taken this risk into account. He would probably have agreed to extending the contract for some days or weeks in case of severe distress of his tenant, yet he would not have agreed to a long and potentially indefinite time prolongation of the contract without receiving any rental payment. In other words, the principle of good faith as used here is not to maintain

\section{Footnote 23 continued}

exercised by virtue, and within the limits, of the social function of contracts" and according to Article 422: "the contracting parties are bound to observe the principles of probity and good faith, both in entering into the contract and in its performance". The general clauses of "social function of contracts" and "good faith" are generally applied by Brazilian Courts to leasing contracts (houses, vehicles etc.) and balanced against the terms of the contracts in order to allow the lessee to keep possession of the immovable or movable good. The leading Brazilian case of green soybean forward contract sale, which was signed between rich traders (buyers) and poor farmers (sellers) in the year of 2003, illustrates one of the most challenging adjudications of the social function of contract and the good faith general clauses just after the new civil code came into force in 2003. In this case, the judges changed the terms of the contract applying the "social function of contracts" with the purpose of balancing inequality and redistributing wealth. Before the court intervention, this type of forward contract sale "created an environment of private credit that collaborated to finance and to expand the Brazilian soybean production. However, after the lawsuits of the poor farmers and the Courts adjudication of Good faith on 2003, there was a decline from 80 to $20 \%$ on signing this type of contract" (Nóbrega 2013: 39). "Those soybean farmers who did not breach their contracts have also been negatively affected by the strategic reactions of trading and processing companies. The concept of "social function of the contract" introduced in Brazilian civil code led to a higher degree of instability in contracts, raising transaction costs and motivating private economic sanctions" (Rezende and Zylbersztajn 2012: 207-208).

24 A prevailing and very wide interpretation (strongly recognized in literature and jurisprudence) of "social function of contract" is proposed by Diniz (2007), who sees the social function as a kind of contractual "super-principle", comprising precepts of public order, good customs, objective good faith, contractual equilibrium, solidarity, distributive justice, etc. According to the author, it should comprise every constitutionally and/or legally recognized value which might be said to have a "collective" or "non-individualistic" character. Each one of these social values could thus be used for interpreting the contents of social function. Timm (2008: 14) states that the social function of contract is regarded as "... a phenomenon referred to as "publicization", "socialization" or even as "constitutionalization" of Private Law, which results in institutes traditionally belonging to Civil Law-such as the contract and property-being guided by redistributive criteria inherent to Public Law." According to Schmidt (2009: 476), from a legislative perspective, the Brazilian provision of "social function of contract" is a unique clause not found in any other country.

25 Latin American countries adopt the statutes of other countries, coming up with dogmatic concepts not found in Europe. Within this scope, social function of a contract is an official dogmatic concept not found in Europe. Another example is the constitutionalization of the contract, which extends contractual rights from the contract. Although this concept was originally created in German literature, according to Nóbrega (2012: 185), the new Constitution of 1988 which restored the democratic regime in Brazil represented a change from the liberal individualistic legal order (strictly rule-based) to a social welfare legal order (principle- and standard-oriented). The "hyperinflation" of principles, general clauses and vague concepts in the new legal order favored a decentralized judge-made legal system, with the mission to pursue "social justice." These have shifted towards a more standard-oriented system and have opened the door to judicial activism that weakens contract enforcement, increasing uncertainty. 
the win-win constellation of the contract under fair conditions, but to destroy it and distribute wealth ex-post from one party to the other. The economic consequences of such judgments are usually unintended, as they will lead to more empty flats since the best legal advice one can give to landlords is to ask for a bank guarantee for an indefinite time, which would exclude tenants with low budgets and no commercial good name from access to such contracts. From an economic perspective this is a waste of economic resources. Unfortunately, this feature of contract law can be observed in many developing countries. ${ }^{26}$

Interfering with the freedom of contract for reasons of social welfare Interference in well-functioning markets by reducing private autonomy therefore often comes at a high cost in terms of economic efficiency, and often leads to large collateral damages for those groups that should be protected by the intervention. This is not to say that contracts lead or can lead to social justice. They are structurally unfit for distributional justice; however, their merit lies in their ability to realize win-win constellations.

The legitimacy of intervening with the freedom of contract for reasons of social welfare is to some extent dependent on what mechanisms exist outside the civil law for achieving distributive justice. Economists usually propose redistributing wealth for social reasons through a redistributive tax and public social welfare system, and to leave private autonomy and freedom of contract, which generates more wealth, intact. Scandinavian countries like Denmark are examples of states in which the legal order does not interfere heavily with contracts and the market, but still achieve a high level of distributive justice through the tax and public social security systems. The rationale for this is that redistributing taxes causes fewer losses in terms of wealth and economic efficiency than interfering in markets and contracts. If, however, such a system does not exist or is in its infancy, the urge to use contract law for purposes of social justice is strong, even if it might lead to dysfunctional markets and heavy social losses in terms of a country's wealth. This tendency can be observed in many developing countries and emerging market economies. The good faith principle can be, and is, used for such purposes, as we have shown in the case of Brazil.

\subsubsection{Enhancement of efficiency through the good faith principle}

The principle of good faith, however, as it was developed by European and especially German scholars, is not aimed at changing the contract into a mechanism for redistributing wealth, but for enhancing and increasing the genuine function of a contract, preserving it as an institution for generating mutual gains under fair conditions or, in economic terms, in order to increase economic efficiency. It saves the parties transactions costs.

\footnotetext{
${ }^{26}$ Hans-Bernd Schäfer met a merchant in New Delhi who had bought a flat for his 10 year-old son and left the flat empty for fear that he might never be able to evict the tenant when his son wanted to live there about 10 years later.
} 
The following example demonstrates this ${ }^{27}$ : Two medical doctors practiced in Hamburg and K./Württ, respectively. As each moved to the other place they agreed to swap their practices. Shortly afterwards, the doctor who moved to Hamburg decided to come back to K./Württ., as his motive for living in Hamburg was lost. He opened a new practice in the vicinity of his old practice. The other doctor went to the court which ruled that the doctor could open a practice in Hamburg but not in the same vicinity for a certain time. ${ }^{28}$ The parties had not stipulated a non-competition clause. However, the good faith principle worked as an implied non-competition clause. In fact, the court asked the following: If fair parties would have considered this risk, how would they have allocated it? It decided that parties would have included a non-competition clause in the contract. This is an ex-post imposition of a non-competition clause into the contract by the court with a re-distributional effect. The court does not, however, intend to redistribute wealth for a social reason. It tries to make this and all similar future contracts more efficient in the sense of maintaining the ex ante win-win constellation and not to allow unfair or opportunistic behavior of one party. ${ }^{29}$

In practice, a court can enhance efficiency through the good faith principle in three ways: by (1) suspending a mandatory rule, (2) suspending a default rule, and (3) allocating risks where the law is silent.

Suspending a mandatory rule The principle of good faith can enhance efficiency by suspending a mandatory rule as the following example shows. The manager of a company sold a piece of the company's land for a bargain price to an employee as a kind of bonus for his long service. The contract was in written form but not notarized and therefore did not meet the mandatory form. The manager assured the employee that he could trust him and that they had a contract. However, the transfer of title was not made later on the ground that the contract was not valid.

In this case, the good faith principle may enhance efficiency if the court suspends the mandatory rule. Otherwise the application of the mandatory rule would expose the employee to the manipulative practices of the management and the board of the company, as he had no realistic chance of insisting on meeting the form requirement.

\footnotetext{
27 NJW 1955, 337.

${ }^{28}$ For the responses by lawyers from different countries to the same problem see Case 19: Doctors swapping practices in Zimmermann and Whittaker (2000: 481 ff.).

29 According to the English perspective, the courts merely want to know what the parties have actually decided; they do not want to tell the parties how they should have decided. Therefore, if this case had been brought to an English court, the court would probably have argued that if they wanted a noncompetition clause, they should have written it into the contract. The court would have said that the parties have not reallocated the risk and that the risk falls on the person who has taken over the practice in Hamburg. On the other hand, a German court would argue that the parties have failed to include such a non-competition clause but they would have done it if they had thought about it. Therefore the court would impose a non-competition obligation. One can concede that English courts come closer to the genuine will of the parties if the absence of good faith forces them to write fully specified contracts. But the transactions costs are high. In addition, the Hayekian argument that courts lack the information to mimic them seems to be overstretched in many such cases.
} 
Suspending a default rule There are some cases in which the contract remains silent but the default rules clearly specify the risk. However, sometimes it is clear that the specification of the risk in a particular case is questionable. Depending on the features of the case, if the court sticks to the law (default rule), the results are absurd. In such cases, the good faith principle provides the judge with a flexibility that he would otherwise not have had.

At this point one can make reference to the default rule regarding the rejection of partial performance. In such cases, even though the risk was explicitly specified in the default rules, an exception can be made if it is required by the principle of good faith. For instance, if the seller offers to deliver 999 packs of rice to the market (instead of 1000) and offers to deliver the remaining one pack the next morning, it would be against the principle of good faith if the buyer rejected such partial delivery. Therefore the court will suspend the default rule.

Allocating risks when the law is silent There maybe cases where both contract and default rules are silent on a matter. In other words, in such cases both contract and default rules are incomplete and they remain silent on the topic of risk allocation, with the consequence that the result might be neither fair nor cost-saving. In such cases, the principle of good faith can provide an efficient risk allocation. For instance, in the example of the medical doctors who swapped their practices the good faith principle can lead to such an efficient risk allocation.

\section{3 "Taming the monster" through an internal dogmatic structure}

In this section we show that the good faith principle is not a port leading to unlimited and willful judicial interpretation, but rather has an internal structure which limits its usage, even though it can be used for an indefinite number of cases and might lead to almost all conceivable legal consequences. For instance, the judge can invalidate the contract, change the price, suspend or change a clause in the contract, or grant injunctive relief, compensation of damages, the disgorgement of profits or a removal claim.

An obvious criticism of the principle of good faith therefore is its generality and broad scope. The judge might become a kind of "philosopher king". In this article we abstain from giving the principle a precise legal definition or to add one to the existing catalogue of definitions. For our purposes it is enough to say that it endows the judiciary with an almost unlimited power to interfere with the contract, that it is used as a last resort when all other methods of interpretation lead to absurd consequences, and that the willfulness in most civil law jurisdictions is removed by giving the principle a highly differentiated internal structure and that like all of contract law it tries to preserve the ex ante win-win property of a contract, allocate risk in a cost efficient way and curb opportunistic behavior of one party.

Jurisdictions that make extensive use of the principle of good faith have developed safeguards to give it structure and to avoid its inflationary use, thus 
"domesticating the monster" (Zimmermann and Whittaker 2000: 22). ${ }^{30}$ More specifically, lawyers in such countries can rely on well-elaborated legal dogmatic forms, which define terms and conditions under which the principle of good faith can be used. ${ }^{31}$ Thus legal security and predictability can be maintained and deviations from the basic concept of a contract can be prevented (Brox 2005: 32 , Rdnr. 689; Hesselink 2010: 623; Baumann 1998a, b: Art. 2, No. 16). In other words, the good faith principle is concretized through its division into categories and subcategories (Fallgruppen) (Medicus 2002: §15, Rdnr. 137ff.; Hesselink 2010: 623; Hausheer and Jaun 2003: Art. 2 ZGB, Nr. 15; Hürlimann-Kaup and Schmid 2010: $\S 7$, Nr. 260; Grüneberg 2010: $§ 242$, No. 2.). ${ }^{32}$ If an individual judge uses the good faith principle in a loose way and out of hand, he and the parties can be almost certain that courts of higher instance will uplift such a decision not based on the state of the legal art. As a result, the good faith principle loses the appearance of a blank check with which a judge can intervene in any contract as he pleases and in accordance with his concept of justice (Roth and Schubert 2012: § 242, Nr. 25). It imposes a series of well-defined checks and legal consequences. Therefore it gives contract law an innovative flexibility as well as the possibility to avoid absurd and unforeseen consequences of formal law without turning law into politics. This dogmatic structure, which reduces its willfulness, can also be observed in Turkish contract law, making the civil law system in Turkey similar to the continental European system, not only in terms of black letter law, but also in terms of the dogmatic structure that governs the use of the good faith principle. For the benefit of our international readership we give here an overview, which is simplified but not overly simplistic, and which aims at showing the differentiated structure of the good faith principle in Turkey (Table 1).

In Turkey as in other civil law countries it occurs quite seldom that the Supreme Court uses the principle of good faith directly. The court resorts to one of these welldeveloped sub-categories and makes direct use of the principle only in cases in which the established use of the good faith principle within one of the subcategories would lead to absurd legal consequences, which rarely occurs.

\subsection{Good faith from an economic perspective in Turkish law}

Now we turn to analyzing decisions of the Turkish Supreme Court, discussing two aspects. Does the court use the good faith principle to redistribute wealth in a way that causes efficiency losses or does it try to allocate risk efficiently and curb opportunistic behavior? Does the court use the good faith principle within the

\footnotetext{
30 Similarly, according to Mackaay (2011: 17), good faith is a guiding principle that is subject to many specific "crystallizations" in order to prevent opportunism; however, considering the need for legal certainty, it is too general to be applied routinely.

${ }^{31}$ For detailed information on these legal dogmatic forms in different countries see Hesselink (2010: 624 ff.).

32 Schmidt (1995: $§ 242$, No. 87) explains this by stating that the legal doctrine has developed an "inner system" (Binnen system) of good faith. According to Hesselink (2010: 644), in near future there will be a practical need to abolish such an inner system, as it will no longer be manageable due to the enormous number of cases based on good faith.
} 
Table 1 The dogmatic structure of the good faith principle in Turkish contract law

\begin{tabular}{|c|c|c|}
\hline Subcategory & Legal requirements & Legal consequence \\
\hline Culpa in contrahendo ${ }^{\mathrm{a}}$ & $\begin{array}{l}\text { Willfully or negligently violating } \\
\text { rules of conduct and damaging the } \\
\text { other party during contract } \\
\text { negotiations }\end{array}$ & $\begin{array}{l}\text { Compensation of reliance } \\
\text { damages under the norms of } \\
\text { contract law }\end{array}$ \\
\hline $\begin{array}{l}\text { Contract with protective effect for a } \\
\text { third party (Vertrag mit } \\
\text { Schutzwirkungen zugunsten } \\
\text { Dritter) }\end{array}$ & $\begin{array}{l}\text { Close connection of a third party with } \\
\text { the contract, } \\
\text { The creditor's interest in protecting } \\
\text { the debtor, } \\
\text { Foreseeability of the responsible } \\
\text { party's interest in the third party at } \\
\text { the time of the contract formation, } \\
\text { The third party's need for } \\
\text { protection (Gauch and Schluep } \\
\text { 2008b: Nr. 3913) }\end{array}$ & $\begin{array}{l}\text { Compensation of damages for } \\
\text { the third party under the } \\
\text { norms of contract law }\end{array}$ \\
\hline $\begin{array}{l}\text { Liability for breach of trust } \\
\text { (Vertrauenshaftung) (Gauch and } \\
\text { Schluep 2008a: Nr. 982 h; } \\
\text { Baumann 1998a, 1998b: Rz. } 105 \\
\text { ff.; Riemer 2003: Nr. 24; Hofer } \\
\text { et al. 2011: Nr. 03.89.; Hausheer } \\
\text { and Aebi-Müller 2012: Rz. } 175 \text { ff; } \\
\text { Kirca 2004: 195) }\end{array}$ & $\begin{array}{l}\text { A special legal relationship between } \\
\text { the parties arising from the good } \\
\text { faith principle, } \\
\text { Acts committed by one of the parties } \\
\text { that lead them to gain the other } \\
\text { party's trust, which is worth } \\
\text { protecting, } \\
\text { Disappointment by the trusting party } \\
\text { against the principle of good faith, } \\
\text { Appropriate causal link between the } \\
\text { act and the damage, } \\
\text { The damage caused by faulty } \\
\text { behavior (Gauch and Schluep } \\
\text { 2008b: Nr. } 982 \mathrm{e} \text { ff.) }\end{array}$ & $\begin{array}{l}\text { Compensation (in principle) in } \\
\text { form of reliance damages } \\
\text { under the rules of contract } \\
\text { law }\end{array}$ \\
\hline $\begin{array}{l}\text { Adaptation of the contract to the } \\
\text { changed circumstances (clausula } \\
\text { rebus sic stantibus) (Article } 137 \\
T C O)^{\mathrm{c}}\end{array}$ & $\begin{array}{l}\text { Emergence of a condition that at the } \\
\text { time of contract conclusion could } \\
\text { not be foreseen by the parties and } \\
\text { that also could not be expected to } \\
\text { be foreseen by the parties with a } \\
\text { reason not originating from the } \\
\text { debtor, } \\
\text { Change in the circumstances present } \\
\text { at the time of the conclusion of the } \\
\text { contract against the debtor in such a } \\
\text { way that demanding performance } \\
\text { from him contravenes the principles } \\
\text { of good faith, } \\
\text { Non-performance by the debtor or, if } \\
\text { already performed, performance by } \\
\text { reserving his/her rights arising from } \\
\text { the excessive difficulty of } \\
\text { performance }\end{array}$ & $\begin{array}{l}\text { Adaptation of the contract, } \\
\text { Termination of the contract if } \\
\text { adaptation is not possible }\end{array}$ \\
\hline
\end{tabular}


Table 1 continued

\begin{tabular}{|c|c|c|}
\hline Subcategory & Legal requirements & Legal consequence \\
\hline $\begin{array}{l}\text { Side obligations (Nebenpflichten); } \\
\text { (breach of which constitute a case } \\
\text { of positive breach of contract } \\
\text { (Positive Vertragsverletzung) }\end{array}$ & $\begin{array}{l}\text { These are either: } \\
\text { Breach of obligations which do not } \\
\text { have an independent purpose but } \\
\text { serve to deliver appropriate } \\
\text { performance of the main and } \\
\text { accessory obligations } \\
\text { (Leistungsbezogene } \\
\text { Nebenpflichten) (such as duty of } \\
\text { information, documentation, co- } \\
\text { operation, disclosure etc.), or } \\
\text { breach of conduct rules } \\
\text { (Verhaltenspflichten) (such as duty } \\
\text { to protect and care) (Schwenzer } \\
\text { 2012: Nr. } 67.08 \mathrm{ff.} \text { ) }\end{array}$ & $\begin{array}{l}\text { Compensation through } \\
\text { expectation or reliance } \\
\text { damages }\end{array}$ \\
\hline $\begin{array}{l}\text { Obligation to contract (Oğuzman and } \\
\text { Barlas 2008: 182) }\end{array}$ & $\begin{array}{l}\text { The claimant's need to contract, } \\
\text { The addressee's dominant position, } \\
\text { The claimant's request, } \\
\text { Lack of valid legal reason for the } \\
\text { rejection of the claimant's request }\end{array}$ & $\begin{array}{l}\text { Obligation to contract, } \\
\text { Compensation of damages } \\
\text { arising from not contracting }\end{array}$ \\
\hline $\begin{array}{l}\text { Principle of trust (Vertrauensprinzip) } \\
\text { in the formation, interpretation and } \\
\text { gap filling of legal transactions } \\
\text { (Riemer 2003: Nr. } 18 \mathrm{ff} \text {; Hausheer } \\
\text { and Aebi-Müller 2012: Rz 98.) }\end{array}$ & $\begin{array}{l}\text { The addressee's rightful acceptance } \\
\text { (under the principle of good faith) } \\
\text { that one's behavior is a declaration } \\
\text { of will directed at him }\end{array}$ & $\begin{array}{l}\text { Formation of contract as } \\
\text { rightfully relied upon by the } \\
\text { addressee }\end{array}$ \\
\hline Misuse (abuse) of right ${ }^{d}$ & $\begin{array}{l}\text { Alternative requirements: } \\
\text { Having no legitimate interest in using } \\
\text { the right, or } \\
\text { Gross disproportionality between the } \\
\text { interest in usage of right and the } \\
\text { damage thus created for another } \\
\text { person, or } \\
\text { Acting against the created trust } \\
\text { (contradictory behavior), or } \\
\text { Usage of rights that are based on } \\
\text { one's immoral act }\end{array}$ & $\begin{array}{l}\text { Loss of using such right, } \\
\text { Injunctive relief against the } \\
\text { right holder }\end{array}$ \\
\hline $\begin{array}{l}\text { Obligations resulting from debtor } \\
\text { circumstances (Faktische } \\
\text { Vertragsverhältnisse) }\end{array}$ & $\begin{array}{l}\text { Benefiting from a publicly available } \\
\text { service without a contract }\end{array}$ & $\begin{array}{l}\text { Compensation through } \\
\text { expectation or reliance } \\
\text { damages under the rules of } \\
\text { contract law }\end{array}$ \\
\hline
\end{tabular}

${ }^{a}$ In Turkish law culpa in contrahendo is regarded as a sub-category of good faith. (Kirca 2004: 142; Hofer et al. 2011: Nr. 03.98; Riemer 2003: Nr. 23; Hausheer and Aebi-Müller 2012: Rz. 160.)

b Similarly to culpa in contrahendo, in Turkish law a contract with protective effect for a third party is regarded as a sub-category of good faith (Kırca 2004: 103; Hausheer and Aebi-Müller 2012: Rz. 195 ff.; Hofer et al. 2011: Nr. 03.103.)

c The clausula rebus sic stantibus principle arises from the principle of good faith (Hürlimann-Kaup and Schmid 2010: Nr. 279; Baumann 1998a, b: Rz. 443; Hausheer and Aebi-Müller 2012: Rz. 225 ff.; Riemer 2003: Nr. 51). However, after the reform of the Turkish Code of Obligations, it is now specifically regulated under Art. 137 TCO

d Misuse (abuse) of a right is regulated under Art. 2/II TCC as follows: "The legal order does not protect an explicit misuse of a right." ("Bir hakkın açıkça kötüye kullanılmasını hukuk düzeni korumaz.") 
Fig. 1 The good faith principle in Turkish Supreme Court decisions, 1993-2013

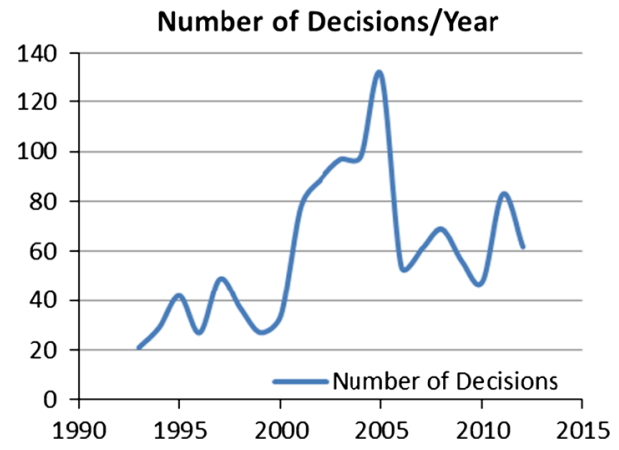

internal dogmatic structure using categories and sub-categories (Fallgruppen) to channel its use and curb judicial activism or do judges use the principle freehandedly? We discuss especially those Supreme Court cases that are found in textbooks on contract law in Turkey, as those cases play a prominent role in shaping the views of Turkish lawyers, scholars and judges.

We also attempt to determine how important the use of this principle in Turkish law actually is. This is difficult, because all Supreme Court decisions are not officially published online or anywhere else. There exist datasets of Supreme Court cases that are used by Turkish law firms and that were assembled and marketed by private companies. These datasets are neither complete nor are they representative. All figures in the following table must therefore be regarded with caution. Neither the absolute numbers nor the changes over time represent any convenient level of accuracy. But the numbers still show that the good faith principle is factually an important principle of Turkish contract law and is often used by the Supreme Court (Fig. 1).

\subsubsection{Lifelong care (YİBGK 5.6.1957 E. 1953/13 K. 1957/20)}

The plaintiff concluded a lifelong care provision contract with a person and fulfilled all of his obligations arising from the contract until the death of the other party. Following his death, when the plaintiff claimed the consideration set forth under the contract, the heirs of the deceased argued that the contract was invalid because of a breach of the form requirement. The court ruled that, once a lifelong support contract or an adoption contract is fulfilled, following the death of the party who receives lifelong support, it constitutes a misuse of right to claim invalidity of the contract due to a breach of form requirements.

The court put the form requirement of a notarized contract aside. This can be criticized on the ground that this form requirement is not only pure formalism but protects vital interests of a house owner against impulsive decisions to buy or sell. In this case, however, the plaintiff could show that it was in the long-term and clear interest of the deceased to receive his services. If this contract were invalid many situations could arise in which one party invests very heavily in a contract without receiving the specific counter-performance. This reasoning is therefore in line with 
economic reasoning, namely preserving the Pareto-improving property of a contract against opportunistic behavior.

\subsubsection{Wooden bars (YHGK 13.1.1965 E. 1964/2 K. 1965/16)}

We add here another good illustrative example that is not related to contract law. Despite being in accordance with construction legislation, blocking the sea view of a neighbor by constructing wooden bars constitutes misuse of right if the constructing neighbor has no interest in such construction.

It is obviously inefficient if the owner of a right could make use of this right with the only purpose being the infliction of damage on another person. Therefore, under Turkish law as in the law of many other jurisdictions, one finds misuse of right as a limit to the right of the owner, which is efficiency enhancing.

\subsubsection{Water service subscription (Yarg 13 HD 24.5.2004 E. 2003/17444 K. 2004/7862)}

This case is related to the "obligation to contract" which originates from the principle of good faith. In this case the state water supply company rejected to make a subscription contract and to supply water services to the owner of a flat by arguing that his previous tenant, who has already been evicted from the flat, had some remaining unpaid bills. The Supreme Court decided that as the company had monopoly position, it hence had the obligation to contract.

The specific aspect of this case is that the supplier of the water service is a monopoly. The customer has no other choice than to buy his water from this monopoly. Moreover, water is a basic good, whose purchase is necessary whatever the costs are. Monopolies therefore must be controlled with regard to the prices they charge and with regard to the terms and conditions under which they supply their products. Contract law here has, to a certain extent, to mimic the rules of public and administrative regulatory law. If the company operated in a competitive environment, there would be no need for the legal system to interfere, but at the same time it would then be highly improbable that a corporation would impose such a clause on a customer for fear of losing him to a competitor. It is therefore fully in line with economic reasoning that in monopoly markets the legal system must cut deeper into the freedom of contract than is reasonable or acceptable in well-functioning markets.

\subsubsection{Illegal electricity usage (YHGK 20.12.2000 E. 2000/3-1803 K. 2000/1813)}

In this case, the respondent used electricity illegally without subscription or signing a contract with the relevant institution. The court ruled that in accordance with the principle of good faith, there is a (contract-like) obligatory relationship between the respondent and the supplier. Therefore, the price calculated by the institution under the Electricity Tariff Regulation must be paid. In other words, the plaintiff cannot argue that his enrichment is lower than the price to be calculated under the Electricity Tariff Regulation or that the institution is not impoverished as much as 
the amount claimed. These defenses would, however, be available without using the good faith principle; that is, if the plaintiff would have to base the claim either on tort law, which leads to damage compensation, or on unjust enrichment. In both cases, either the amount of damages inflicted on the company or the defendant's unjust enrichment might be lower than the regulated price for electricity.

Moreover, this case shows that the result is not only in line with fairness or justice, but also that an alternative solution would lead to wrong incentives. If one would not assume a contract in this case, which entitles the electricity company to collect the actual price for electricity, this would give incentives to all to consume electricity without contract and burden the electricity company with the costs of the burden of proof for damages or the amount of unjust enrichment later on. This would then lead to an increase of illegal electricity consumption.

\subsubsection{The bridal gift (Yarg 2 HD 26.10.1972 E 6437 K 6134 (IBDD 1972))}

In this case a minor, the respondent made a gift to his prospective wife. 11 years after they married, he claimed that such a gift was invalid due to his lack of capacity. According to the Supreme Court, such a claim is against the good faith principle. In this decision, the Court did not expressly refer to any sub-categories of good faith but it can be inferred that the court sees the respondent's act as a misuse of right.

It is difficult to make a clear statement on whether this solution is not only in line with the idea of protecting women, or the idea of justice, but also whether it is in line with efficiency considerations. It is clear that this decision, if it is a general rule, comes at the cost of reducing the protection of minors by a judge-made rule. The protection of minors has high economic value because if minors could conclude valid contracts, the resources they would transfer would in many cases not go to the highest valued user. The protection of minors therefore does not only protect the minors themselves but also serves the general purpose of not wasting resources. If therefore the courts reduce this protection, it comes at a cost to the minor and the society and it is impossible to say prima facie whether these costs can be regarded as lower than the protective effect for the woman. The court, however, made it clear that it regarded the time lag between the formation and the refutation of the contract as essential. If the man had refuted the contract shortly after the marriage or after one or two years, the ruling would have come close to a revocation of the protection of minors and would then have amounted to a redistribution of wealth, which can hardly be defended on economic grounds. After 11 years, however, the situation is different. The economic rationale for adverse possession already applies here to some extent.

In addition, the court has stressed the fact that in Turkey gifts from the husband to the bride before marriage are wide-spread and common custom. Therefore one can at least insinuate that this ruling destroys incentives for post-contractual opportunistic behavior by not allowing the husband to refer to the invalidity of the contract upon formation. Even if it is undeniable that this judge-made rule comes at the cost of reducing the protection of minors and even, as explained, at an economic 
cost, it might still have an efficiency gain in terms of reducing opportunistic behavior after the marriage is concluded.

\subsubsection{Allocation of jointly-owned immovable (Yarg 6 HD 19.4.2005 E. 2005/2112 K. 2005/3863)}

In a case of joint ownership the parties allocated their immovable by a written protocol (against the official form requirement which required parties to conclude such a contract at the land registry), and each owner rented out his part of the immovable to third parties for the last couple of years. While everybody used his/ her part as such, one of the parties sold his/her share to a third person. Following such sales, one shareholder wanted to use his preemption right. The court ruled that if a party, who did not object to allocation before, wants to use his/her preemption right in a case of sale to a third party, this is against the principle of good faith. Also in this decision, the Supreme Court did not expressly refer to any sub-categories of good faith, but it can be inferred that the court assesses the respondent's act to be a misuse of right.

Again, this is a ruling in line with economic considerations. It is aimed at curbing post-contractual opportunistic behavior. The mandatory form requirement (that the parties must conclude such a contract at the land registry) is set aside by the court, because its rationale does not apply to the case and the right from it is used in an opportunistic way. Form requirements, such as written form or notarized form, have the rationale of protecting an actor against impulsive or uninformed decisions, which are not in line with his constant motives and long-term preferences. The actor might regret the decision after reconsidering it. They have therefore a similar rationale as, for instance, cooling-off periods in consumer contracts. In the present case, the joint-owners of the immovable had agreed to end their joint-ownership and replace it by single ownerships after dividing up the property. The joint-owners had also reached an agreement on the division and distribution of the assets between them. The use of the immovable by the single owners had been agreed in a former protocol and only after a considerable time after the agreement had one of the jointowners made use of his pre-emption right. It is therefore obvious that he used his right because he regretted his prior decision as being wrong given the changed circumstances at the time of decision-making, because new circumstances had arisen that made it advantageous for him to opt-out of the agreement. ${ }^{33}$

\footnotetext{
33 According to an opinion, in such cases, it cannot be argued that a joint owner does not have a legitimate interest in using his/her preemption right. Accordingly, by way of using the preemption right, a stranger's entry into the joint-ownership union is prevented. Moreover, such third person is not bound with the agreement, which regulates the way of utilization of the jointly owned property. In this vein, see Sirmen 2014: 473), Oğuzman/Seliçi/Oktay-Özdemir (2012: 563-564). In one of its decisions (YHGK 29.6.1990 E. 1990/6-30 K. 1990/441), the Supreme Court ruled as follows "Unless there is an agreement that is entered into by all joint-owners, if some of the joint-owners use certain parts of the jointly owned property, utilization of the legal preemption right by the other joint-owners in case of share sales is in accordance with the purpose of the right." In the case at hand (Yarg 6 HD 19.4.2005 E. 2005/2112 K. 2005/3863), despite being against form requirements, the allocation protocol has been signed by all jointowners. Therefore, we still think that there is a breach of good faith principle and the Supreme Court's decision is in line with economic reasoning.
} 


\subsubsection{High interest rate (YHGK 7.4.2004 E. 2004/3-203 K. 2004/213)}

This case concerns a cell phone subscription contract and the interest rate applicable to overdue bills. The interest rate was not set in the contract, but the GSM operator was given the authority to set it unilaterally. Accordingly, the GSM operator applied an interest rate of $12 \%$ per month, which was higher than the $8 \%$ interest rate applied by competitors. The court ruled that the GSM operator's freedom to set the interest rate is not unlimited and that it amounts to a misuse of right to use such a freedom in a way that applies a $12 \%$ rather than a $8 \%$ interest rate.

In this case we wish to express some doubt about this decision. First, it must be understood that this is not a case of a judicial control of standard form clauses. ${ }^{34}$ The avoidance of this clause in a case of judicial control of standard form clauses would in our view be unproblematic, as asymmetric information between the drafter of the contract and the consumer makes this clause a surprising clause, which for this reason alone would make the clause void.

The Supreme Court assumed that the clause is in principle valid, as if it had been negotiated between the parties, but maintained that the only way this clause could be used without violating the good faith principle was to fix an interest rate not higher than the interest rate of competing companies. We believe that this is overstretching the principle of good faith, because to fix an interest rate for overdue bills that is not only higher than the market rate but also even higher than that of competitors might be a legitimate business strategy. If the GSM operator makes it clear to the subscriber that it becomes very costly for a subscriber not to pay bills when they are due, this practice signals to all buyers that subscribers who pay their bills on time are very welcome but that subscribers who do not pay on time are not welcome by the company and should approach another GSM operator. The high interest rate can therefore be regarded as a kind of contractual fine for not paying bills correctly. The high interest rate deters defaulting customers and saves the company the cost of controlling money transfers by sending reminders, opening court proceedings etc. Therefore, as the company concentrates on good customers, it can offer them a lower price for the specific performance. Another company might concentrate on less reliable customers and offer them a contract in which they do not levy overdue charges at all, instead financing these extra costs with a higher price that attracts tardy customers. This is for instance the business model of some consumer banks concentrating on customers with a history of not being reliable debtors. Determining the viability and validity of business models is part of the functioning of the market and should not be made possible or impossible by way of court decisions. ${ }^{35}$

If a company wants to concentrate its business operations on good customers and wants to leave the other customers to their competitors, there is nothing to be criticized as long as the customers do not suffer from the exploitation of either

\footnotetext{
34 Judicial control of standard form clauses entered into Turkish consumer protection law with an amendment dating from 6 March 2003.

35 Our interpretation of this clause implies that the GSM operator at least had some reasonable discretion and was not forced to fix an interest rate, which is exactly the market interest rate of the competitors. One can also agree that the principle of good faith becomes important again if the user of this clause makes an unreasonable use of his discretion.
} 
market power or asymmetric information, both being excluded here. This is in our view one of the very few cases in which an undue use of the good faith principle is made, cutting into private autonomy in a competitive market and in a way which a fair but self-interested party might not have agreed to if negotiated during the time of contract formation. ${ }^{36}$

We must emphasize, however, that the decision can be criticized on economic grounds only if the interest clause in the contract was not surprising for the customer and that therefore no asymmetric information existed between the parties. The decision would be in line with economic reasoning if one assumed that the buyer typically does not read or understand the clause, which leaves the fixing of the high interest rate to the seller without causing a market reaction of the reliable but uninformed consumer.

\subsubsection{Long lease in foreign currency (YHGK 7.5.2003 E. 2003/13-332 K. 2003/340)}

In this case, the parties concluded a five-year lease contract in foreign currency (US dollars). Approximately six months after contract formation a sudden and severe currency depreciation doubled the value of the rent in terms of Turkish liras. The court considered the possibility that such changes might lead to a collapse of the contract, which is a sub-category of the good faith principle.

Particularly in this decision and in general, the court ruled that change in currency is foreseeable; hence no adaptation is possible. Again, this is fully in line with economic considerations. In Turkey sudden exchange rate changes are not seldom. Typically, parties who make a contract denominated in foreign currency take this into account. They either explicitly or implicitly allocate this risk via the price of the lease contract. If a court would change the price in favor of the plaintiff, this would lead to a reallocation of risk in his favor, which he has already accepted as part of the rental price. This price would typically be higher if the rental contract had been concluded in local currency.

\subsubsection{Agricultural lease (YHGK 11.11.2009 E. 2009/14-456 K. 2009/496)}

In this case the court accepted that, in an agricultural lease, if the amount of products were very low due to force majeure or natural disaster (in this case excessive draught), adaptation (decrease) of the contractually stipulated lease price is applicable. In fact, the lease contract concerned an olive grove and the court ruled that excessive draught was extraordinary and unforeseeable at the time of contract formation.

This is related to exceptionally improbable events that parties do not foresee and stipulate in the contract and can be regarded as an efficiency increasing reconstruction of the fully specified contract, as parties typically do not consider very remote events and internalize them into the price. Here the default rule, under which the stipulated price must be paid regardless of the amount of product

\footnotetext{
36 The only way to defend this decision would be to regard it as a quasi-consumer protection case in the sense that such clauses remain unknown to the buyer before he enters into the contract; hence they are not to be taken into consideration. However, this possibility, which would legitimize the avoidance of the unexpected clause, is not offered in the decision.
} 
harvested, is replaced. Again, the case is in line with economic reasoning. Foreseeable damages and risks explicitly or implicitly become part of the contract. Either the parties allocate them explicitly in a way that differs from the default rule or, if the parties do not alter the default rule, the risk allocation of the black letter law is reflected in a lower price for the good or service, therefore compensating the tenant for the risk from foreseeable harvest fluctuations. If, however, the risk is unforeseeable and remote in the sense that most sellers do not take it into account, the default rule will lead to an ex-post income redistribution for which no provision in the price was made. In the decision, it was made clear that (unlike the former case) the draught was unforeseeable.

\subsubsection{The propane cylinder (YHGK 6.5.1992 E. 1992/13-213 K. 1992/315)}

This case is concerned with the explosion of a malfunctioning and non-gastight propane cylinder. The explosion not only inflicted damages on the buyer of the cylinder, but also on a third person whom the buyer called in for help and who was injured in spite of trying to take necessary precautions. Although there was no contractual relationship between the third person and the seller, the court ruled that the contract between the seller and the buyer was a "contract with protective effect for a third party" (Vertrag mit Schutzwirkung zugunsten Dritter). Therefore the third party had not only the weaker tort claim but rather a contractual claim against the supplier. Consequently, the relatively long contractual limitation period of 10 years applied to the case.

The economic analysis of this case again requires an answer to the question whether, in the pre-contractual situation, the buyer and the firm delivering the gas would in a fully specified contract have agreed to extend the contractual liability to persons other than the actual parties to the contract. One could ask what kind of protection the contract serves, because the victim has a tort claim in any case and is entitled to damage compensation. However, under Turkish law, the limitation period for contractual claims is longer than the limitation period for tort law claims. The protection level of contract law is therefore higher than the protection level of tort law. ${ }^{37}$

\footnotetext{
37 In Turkish law, the injured party has a better legal position under contract law than tort law. This has four main reasons: the longer limitation period; strict liability for employees and assistants; presumption of faulty breach; and compensation of pure economic loses. First, in tortious claims the limitation period is 2 years after learning about the damage and the offender, and 10 years after the tortious act (TCO Art. 72); whereas limitation period for contractual claims is 10 years at all times (TCO Art. 146).The practical difference is that, when one relies on the rules of contract law, a claim might still be made under contract law when it has expired under tort law. Secondly, in tortious liability the employer may be released from liability by proving that he showed the due level of care in choosing, instructing and inspecting the employee (TCO Art. 66/2); whereas if the employee damages the other party to the contract, the employer has no such possibility to be released from liability by proving his due level of care (TCO Art. 116). Third, with a tortious act the injured party must prove the fault of the offender (TCO Art. 50/1); however, in breach of contract, the burden of proof is reversed, which means that the breaching party must compensate unless he/she can show that he has no fault (TCO Art. 112). Finally, in tort law pure economic losses can be recovered only if there is a protective norm, or the offender has acted intentionally and against good faith; however, if there is a contractual relationship between the offender and the injured party, such losses are always recoverable.
} 
In a fully specified contract, the company delivering the gas would agree to this additional level of protection by extending the contract to third persons only if the buyer would be willing to pay the expected differential costs for better protection by contract law, as compared to tort law. The buyer, however, would only be willing to pay this additional price for the better protection for persons for whom he cares or feels a special obligation, like members of his family or other people very close to him, but not to strangers. It is remarkable that the Turkish court makes just this distinction and extends the protective effect of the contract exclusively to those people who are close to the contracting party, but not to strangers. It uses therefore an implicit economic logic, as the distinction between people close to the party and people not close to the party is just the same as the distinction between those people for whom the party would be willing to pay for the additional protection (compared with the protection under tort law, which is not dependent on willingness to pay or on consent of the tortfeasor) and those for whom he would not be willing to pay. ${ }^{38}$ Again, this decision represents another example for reconstructing the fully specified contract and is in line with economic reasoning. And again, this case does not display any reason for assuming that any ex-post income redistribution or wealth redistribution for social purposes was intended. This, of course, includes people one invites into one's own house in order to receive help.

\subsubsection{Invalid sales of flats (YİBK 30.9.1988 E. 1987/2 K. 1988/2)}

A landowner signed a contract with a contractor, according to which the contractor had to construct a building on the landowner's land in return for ownership of one or more flats. Before starting with the construction work, the contractor, in order to finance his work, sold these flats to third parties with invalid, non-notarized contracts. The buyers paid the price for the flat, but later on the contractor argued that he had no obligation to transfer the title of ownership to the buyers since there was no valid contract. A particular and typical feature of the case is that the value of the flat had risen in the meantime to a higher level than the price the buyer had paid. Without the contract, the buyers would have had only a claim from unjust enrichment, which includes the repayment of the price plus interest, but the buyers would have lost any gain from the price increase of the real estate. The court ruled that the invalidity claim based on the disregard of form requirements constituted an abuse of right.

One could argue that this is an obvious case of culpa in contrahendo, as it concerns a violation of pre-contractual duties on part of the seller. The contractor as an expert on real estate knew or must have known that the contract had to be concluded in official form, and that not to disclose this to the buyer was a clear violation of pre-contractual duties. However, the rule of culpa in contrahendo

\footnotetext{
38 Own translation from Turkish: "In the disputed case, the seller (dealer of propane cylinder) has no contractual primary obligation to the plaintiff, who is a third party to the sales contract; however, the protection obligation that the debtor has to the creditor extends to the people who are closely connected to the creditor or under protection due to their close connection to the performance." YHGK 6.5.1992 E. 1992/13-213 K. 1992/315.
} 
would have entitled the buyers only to damage compensation and the negative interest, which excludes profits made from the specific contract. The court decided that this was a misuse of right and that the title must be transferred to the buyer so that he can then receive the benefit from the substantial increase in value. Again, one can argue that this solution is in line with economic reasoning, because it prevents parties from engaging in ruthless opportunistic behavior in a precontractual situation, such as tricking a partner into a contract in order to finance an investment without letting him participate in its return. Opportunistic construction firms could otherwise finance their investment by shifting all risk to the buyer. They could transfer the title of ownership if real estate prices were to decrease during the period of construction. And they could deny transferring the title whenever prices of real estate increased and thus get a cheap credit from someone who believed to have acquired ownership. From an economic perspective, it is therefore to be welcomed that the Supreme Court did not use the culpa in contrahendo rule but the abuse of right rule, which restores the contract and protects the legitimate expectations of those buyers and financiers of the project who are not familiar with form requirements.

\subsubsection{Non-disclosure (Yarg 13 HD 13.11.1995 E. 1995/9375 K. 1995/9860)}

A civil servant concluded an exclusive distributorship agreement with a merchant, but failed to disclose the information that he was a civil servant. Under Turkish law it is forbidden for civil servants to engage in any commercial activity. Therefore, the contract between the parties was invalid. ${ }^{39}$ The 13 th Chamber of the Supreme Court found then on-disclosure of being a civil servant, and could not engage in commercial activity to be against the good faith principle. Consequently, the court ruled that the civil servant was to be held liable due to culpa in contrahendo, leading to compensation for reliance damages.

The case above shows that the Turkish Supreme Court applies a duty to disclose information in a way that serves a productive purpose. The duty to disclose and the resulting damage compensation in case of violation provide incentives to not engage in an illegal transaction. Without this duty to disclose, incentives are created for tricking a merchant into an invalid contract and for investing in such a contract, and this investment might be sunk and lost before the error can be corrected. Therefore this rule prevents resources from being wasted, bringing this decision in line with economic reasoning. In general, it seems that the Turkish Supreme Court does not use the rule of pre-contractual disclosure indiscriminately and especially not in such cases in which non-disclosure generates incentives to gather socially productive information.

\footnotetext{
39 In its decision dated 12 March 1997, the Assembly of Civil Chambers, which is the higher chamber of the Supreme Court, interpreted the rule prohibiting the conclusion of commercial contracts by civil servants. Unlike the 13th Chamber, the Assembly ruled that such contracts are not invalid due to prohibition in the law. According to the Assembly, the civil servant will, however, be liable due to nonperformance of his contractual obligations. See Yarg HGK, 12.3.1997, E. 1996/13-850 K. 1997/186.
} 


\section{Conclusion}

In the introductory parts of this article we pointed to the huge potential benefits, but also to the pitfalls of the good faith principle. The principle might be used or misused as an instrument for redistributing wealth between contractual parties in a way in which these parties would not have agreed to under fair conditions in a precontractual situation. Moreover, courts might use the principle for the promotion of ideology, as could be observed in the period of totalitarianism in European countries.

The potential benefit of the good faith principle is, however, that it provides courts with the flexibility to avoid unintended and absurd consequences of the formal law, which fair parties themselves would have avoided in a fully specified contract in the absence of transactions costs. This excludes unfair distributional effects that neither party would have agreed to, as well as unnecessary costs of risk allocation. If the court restricts the application of the good faith principle to these functions, it provides elasticity that otherwise would not exist if courts were to strictly use the rules laid down in black letter law. Furthermore, it saves transactions costs for parties and is therefore in line with economic reasoning.

We discussed landmark cases of Turkish law and asked whether the decisions of the Supreme Court can be understood either as efforts to improve the cost-efficiency of risk allocation in a contract and remove opportunistic behavior, therefore providing a valuable service to parties and saving them transactions costs, or whether these decisions reflect the motivation to redistribute wealth ex-post or serve an ideological purpose, therefore affecting the private autonomy on which the concept of contract is based.

We have reached the conclusion that the Turkish Supreme Court refrains from ex-post redistribution of wealth for purely social reasons, as well as from ideological bias. This does not only hold with respect to the cases discussed in this paper, but is a general feature of all cases we could find in the database on the decisions of the Turkish Supreme Court-even though we cannot exclude that a contrary case might also exist. The principle of good faith in Turkey is therefore, as in many other Western jurisdictions, a valuable service for parties in order to preserve a fair and equitable risk distribution even if black letter law or the contract itself fails to do so. This saves transactions costs.

What explains this remarkable feature, which seems, for instance, to be different from the situation in Latin American countries? For instance, in Brazil concepts like "the social function of a contract" or the "constitutionalisation of contract law" are used to infringe upon the idea of a contract as a consensual agreement in favor of a more equitable income distribution to which the contracting parties would not have agreed under fair conditions. We could not find such tendencies in the Turkish jurisdiction. We propose here a tentative explanation. The former Turkish law of obligations, which even constitutes the basis of the current code, was introduced in 1926 and was a legal transplant from the Swiss Civil Code and Code of Obligations. Since then Turkish legal scholars and courts havenot developed their own indigenous dogmatic superstructures on this code, but instead followed and adapted 
the European developments, especially in Switzerland and Germany. This applies also to those legal dogmatic developments that give the principle of good faith a solid interior structure and split it up into categories and sub-categories with different legal elements and consequences. Therefore Turkish contract law not only inherited the contractual rules of the Swiss Code, but judges, lawyers and scholars also use the dogmatic developments that give structure to such blanket clauses like the good faith principle, thus preventing them from developing something which is opposed to the idea of contract. ${ }^{40}$

Conflict of interest The authors declare that they have no conflict of interest.

\section{References}

Akyol, Ş. (2006). Dürüstlük Kuralı ve Hakkın Kötüye Kullanılması Yasă̆ı. İstanbul: Vedat.

Ayres, I., \& Gertner, R. (1989). Filling gaps in incomplete contracts: An economic theory of default rules. Yale Law Journal, 99(1), 87-130.

Baumann, M. (1998a). In M. Baumann et al. (Ed.), Kommentar zum schweizerischen Zivilrecht (Zürcher Kommentar), Bd. I, Einleitungstitel zum ZGB, Art. 1-7 ZGB. Zürich: Schultess.

Baumann, M. (1998b). In P. Gauch \& J. Schmid (Eds.), Kommentar zum Schweizerischen Zivilgesetzbuch, I. Band, Einleitung-Personenrecht, Einleitung, 1. Teilband, Art. 1-7 ZGB. Zürich: Schultess.

Baygın, C. (2000). Culpa in Contrahendo Sorumluluğu ve Amerikan Hukukundaki Uygulaması. Atatürk Üniversitesi Erzincan Hukuk Fakültesi Dergisi, 4(1-2), 345-377.

Bridge, M. G. (1984). Does Anglo-Canadian contract law need a doctrine of good faith? The Canadian Business Law Journal, 9(4), 385-426.

Brox, H. (2005). Allgemeiner Teil des BGB. Köln: Carl Heymanns Verlag.

Burton, S. J. (1980). Breach of contract and the common law duty to perform in good faith. Harvard Law Review, 94(2), 369-404.

Card, D., \& Krueger, A. B. (1995). Myth and measurement: The new economics of the minimum wage. Princeton: Princeton University Press.

Cooter, R., \& Ulen, T. (2012). Law and economics. Boston: Addison-Wesley.

Diniz, M. H. (2007). Curso de direito civil brasileiro, v. 3. Teoria das obrigações contratuais e extracontratuais. 23. ed., rev. e atual. de acordo com a Reforma do CPC. São Paulo: Saraiva.

Dural, M., \& Sarı, S. (2010). Türk Özel Hukuku, Cilt I, Temel Kavramlar ve Medeni Kanunun Başlangıç Hükümleri. İstanbul: Filiz.

Gauch, P., \& Schluep, W. R. (2008a). Schweizerisches Obligationenrecht Allgemeiner Teil, Band I. Zürich: Schultess.

Gauch, P., \& Schluep, W. R. (2008b). Schweizerisches Obligationenrecht Allgemeiner Teil, Band I (Vol. I). Zürich: Schultess.

Goode, R. (1992). The concept of “good faith” in English law. http://www.cisg.law.pace.edu/cisg/biblio/ goode1.html. Accessed 18 Feb 2014.

Grüneberg, C. (2010). In O. Palandt (Ed.), Bürgerliches Gesetzbuch. München: Verlag C.H. Beck.

Harrison, J. L. (1995). Law and economics. St. Paul: West Publishing.

Hausheer, H., \& Aebi-Müller, R. E. (2012). In H. Hausheerand, \& H. P. Walter (Eds.). Berner Kommentar, Bd. I/1, Einleitung, Art. 1-9 ZGB. Bern: Stämpfli.

Hausheer, H., \& Jaun, M. (2003). Die Einleitungsartikel des ZGB-Art. 1-10 ZGB. Bern: Stämfli.

Hesselink, M. W. (2010). The concept of good faith. In A. S. Hartkamp, et al. (Eds.), Towards a European Civil Code (pp. 619-649). Alphenaan de Rijn: Kluwer.

Hofer, S., Hrubesch-Millauer, S., \& Roberto, V. (2011). Einleitungsartikel und Personenrecht. Bern: Stämpfli.

\footnotetext{
${ }^{40}$ If one reads a Turkish monograph on civil law or the law of obligations, one will see that most of the references are made to Swiss or German books and articles.
} 
Hürlimann-Kaup, B., \& Schmid, J. (2010). Einleitungsartikel des ZGB und Personenrecht. Zürich-BaselGenf: Schultess.

Kaplow, L., \& Shavell, S. (2002). Economic analysis of law. In A. J. Auerbach \& M. Feldstein (Eds.), Handbook of public economics (pp. 1661-1784). Amsterdam: Elsevier.

Kırca, Ç. (2004). Bilgi Vermeden Dolayı Üçüncü Kişiye Karşı Sorumluluk. Ankara: Banka ve Ticaret Hukuku Araştırma Enstitüsü.

Laithier, Y. (2003). Comparative law and economic efficiency. Henri Capitant Law Review. http:// henricapitantlawreview.net/article.php?lg=en\&id=228. Accessed 18 Feb 2014.

Mackaay, E. (2009). The economics of civil law contract and of good faith. https://papyrus.bib.umontreal. ca/xmlui/bitstream/handle/1866/3016/Mackaay_Trebilcock-Symposium\%20_3_.pdf?sequence=1. Accessed 18 Feb 2014.

Mackaay, E. (2011). Good faith in civil law systems - a legal-economic analysis. CIRANO—Scientific Publications 2011 s-74. http://papers.ssrn.com/sol3/papers.cfm?abstract_id=1998924. Accessed 18 Feb 2014.

Mackaay, E., \& Leblanc, V. (2003). The law and economics of good faith in the civil law of contract. https://papyrus.bib.umontreal.ca/xmlui/bitstream/handle/1866/125/Article\%20papyrus.pdf?sequence=1. Accessed 18 Feb 2014.

Medicus, D. (2002). Allgemeiner Teil des BGB. Heidelberg: C.F. Müller Verlag.

Merz, H. (1962). Kommentar zu Art. 2 ZGB. In H. Becker (Ed.), Berner Kommentar-Kommentar zum Schweizersichen Zivilrecht, Band I, Einleitung und Personenrecht, Einletung, Artikel 1-10 ZGB. Bern: Verlag Stämfli \& Cie.

Miller, A. D., \& Perry, R. (2013). Good faith performance. Iowa Law Review, 98(2), 689-745.

Musy, A. M. (2000). The good faith principle in contract law and the precontractual duty to disclose: Comparative analysis of new differences in legal cultures. http://www.icer.it/docs/wp2000/ Musy192000.pdf. Accessed 18 Feb 2014.

Nicholas, B. (1973). Rules and terms-civil law and common law. Tulane Law Review, 46(4), 946-972.

Nóbrega, F. F. B. (2012). Custos e Benefícios de um Sistema Jurídico baseado em Standards: uma análise econômica da boa-fé objetiva. Economic Analysis of Law Review, 3(2), 170-188.

Nóbrega, F. F. B. (2013). The economic analysis of trust in contracts: Judicial intervention and the problem of opportunism premium superior to the good-faith premium (working paper). In $I V$ Brazilian Congress of Law and Economics, Rio de Janeiro, (pp. 1-46). http://www.congresso.abde. com.br/index.php/VI_ABDE/VI_ABDE/paper/download/184/70. Accessed 18 Feb 2014.

O’Connor, J. F. (1990). Good faith in English law. Aldershot: Darmouth.

Oğuzman, M. K. (1988). Dürüstlük Kuralına (MK m. 2) Başvurma Hususunda Bazı Yargıtay Kararlarının Eleştirilmesi. In Prof. Dr. Yaşar Karayalçın'a 65'inci Yaş Armă̆anı (pp. 407-415). Ankara: Türkiye İş Bankası Kültür Yayınları.

Oğuzman, M. K., \& Barlas, N. (2008). Medeni Hukuk. İstanbul: Vedat.

Oğuzman, M. K., Seliçi, Ö., \& Oktay-Özdemir, S. (2012). Eşya Hukuku. İstanbul: Filiz.

Okun, A. M. (1975). Equality and efficiency: The big tradeoff. Washington, DC: Brookings Institution.

Piers, M. (2011). Good faith in English law-could a rule become a principle? Tulane European and Civil Law Forum, 26(1), 123-169.

Posner, R. A. (2007). Economic analysis of law. Austin: Wolters Kluwer.

Reich, N. (1972). Sozialismus und Zivilrecht. Frankfurt: Athenäum Verlag.

Rezende, C. L., \& Zylbersztajn, D. (2012). Pacta Sunt Servanda versus the social role of contracts: The case of Brazilian agriculture contracts. Revista de Economia e Sociologia Rural, 50(2), 207-222.

Riemer, H. M. (2003). Die Einleitungsartikel des Schweizerischen Zivilgesetzbuches (Art. 1-10 ZGB). Bern: Stämpfli.

Roth, G. H., \& Schubert, C. (2012). In. F.J. Säcker, \& R. Rixecker (Eds.), Münchener Kommentar zum Bürgerlichen Gesetzbuch. München: Verlag C.H. Beck.

Schäfer, H. B., \& Ott, C. (2004). The economic analysis of civil law. Cheltenham: Edward Elgar.

Schmidt, J. (1995). In J. v. Staudinger (Ed.), Kommentar zum Bürgerlichen Gesetzbuch mit Einführungsgesetz und Nebengesetzen; Zweites Buch Recht der Schuldverhältnisse; Einleitung zu $\S \S 241$ ff; $\$ \S 241-243$. Berlin: Sellier de Gruyter.

Schmidt, J. P. (2009). Zivilrechtskodifikation in Brasilien: Strukturfragen und Regelungsprobleme in historisch-vergleichender Perspektive. Tübingen: Mohr Siebeck.

Schwartz, A. (2003). The law and economics approach to contract theory. In D. E. Wittman (Ed.), Economic analysis of the law. Maiden: Blackwell.

Schwarz, A. (1946). Medeni Hukuka Giriş. İstanbul: Adnan Kitabevi. 
Schwenzer, I. (2012). Schweizerisches Obligationenrecht Allgemeiner Teil. Bern: Stämpfli.

Sepe, S. M. (2010). Good faith and contract interpretation: A law and economics perspective. Arizona Legal Studies, Discussion Paper No. 10-28. http://papers.ssrn.com/sol3/papers.cfm?abstract_id= 1086323. Accessed 18 Feb 2014.

Shavell, S. (2004a). Economic analysis of law. New York: Foundation Press.

Shavell, S. (2004b). Foundations of economic analysis of law. Belknap: Cambridge.

Sims, V. (2004). Good faith in English contract law: Of triggers and concentric circles. Ankara Law Review, 1(2), 213-232.

Sirmen, L. (2014). Eşya Hukuku. Ankara: Yetkin.

Steyn, J. (1997). Contract law: Fulfilling the reasonable expectations of honest men. Law Quarterly Review, 113(3), 433-442.

Summers, R. S. (1968). "Good faith" in general contract law and the sales provisions of the Uniform Commercial Code. Virginia Law Review, 54(2), 195-267.

Sungurbey, İ. (1974). Medeni Hukuk Sorunları, İkinci Cild. İstanbul: İstanbul Üniversitesi Yayınları No. 1956.

Teubner, G. (1998). Legal irritants: Good faith in British law or how unifying law ends up in new divergences. The Modern Law Review, 61(1), 11-32.

Timm, L. B. (2008). The social function of contract law in Brazilian Civil Code: distributive justice versus efficiency-lessons from the United States. http://escholarship.org/uc/item/29x696kf.pdf. Accessed 18 Feb 2014.

Veljanovski, C. (2007). Economic principles of law. Cambridge, New York, Melbourne, Madrid, Cape Town, Singapore, São Paulo: Cambridge University Press.

Whittaker, S. (2013). Good faith, implied terms and commercial contracts. Law Quarterly Review, 129(3), 451-469.

Zimmermann, R., \& Whittaker, S. (2000). Good faith in european contract law. Cambridge: Cambridge University Press. 